\title{
Development and Evaluation of Whey Based RTS Beverage from Ripe Banana Juice
}

\section{N. K. Dhamsaniya* and A. K. Varshney}

Department of Processing and Food Engineering, College of Agricultural Engineering and Technology, Junagadh Agricultural University, Junagadh-362 001, Gujarat, India

\begin{abstract}
The investigation was aimed to develop a delicious and nutritious RTS beverage from the ripe banana juice and milk whey. The $M$. arvensis extract was used as a natural flavoring agent. The proportion of banana juice, $M$. arvensis extract and milk whey was varied from $5-15 \mathrm{ml}, 1-5 \mathrm{ml}$ and $72-86 \mathrm{ml}$ per $100 \mathrm{ml}$ of the prepared beverage, respectively. The screening of beverage samples was done on the basis of their physicochemical and sensory characteristics. As a result of various studies conducted for optimizing the proportions; an acceptable whey banana RTS beverage was prepared having $15 \mathrm{ml}$ banana juice, $3 \mathrm{ml} M$. arvensis extract, $8 \mathrm{~g}$ sugar powder and $77 \mathrm{ml}$ milk whey per $100 \mathrm{ml}$ of the prepared beverage, respectively. The developed RTS beverage could be recommended for the large scale production at industrial level.
\end{abstract}

Keywords: Banana juice; Whey; Beverage; RTS; Sensory characteristics

\section{Abbreviation: RTS: Ready to Serve}

\section{Introduction}

Banana (Musa paradisiaca L.) is one of the most widely grown fruit, cultivated over 170 countries along the tropic and sub-tropics of the Capricorn. After ripening, banana fruit is highly susceptible to deterioration. Its considerable amount is wasted due to lack of efficient processing techniques that are unique to ripe banana. Very few processed products are available in the market, primarily due to difficulty in retaining the characteristics color, flavor and texture during the processing of ripe banana [1]. Hence, it is utmost important to process the large amount of surplus ripe banana fruits available in the entire banana growing regions for preventing their loss after ripening.

Milk whey is one of the highly nutritious by-products obtained from the dairy industry producing cheese, chhanna and paneer. It constitutes almost $45-50$ percent of total milk solids, 70 percent of milk sugar mainly lactose, 20 percent of milk proteins, $70-90$ percent of milk minerals and almost all the water soluble vitamins originally present in milk [2,3]. It resulted into unraveling the secrets of whey proteins and other components and established a sound basis for their nutritional and functional value [4]. Several authors have investigated the possibility of utilizing the milk whey in the fruit beverage preparation [5-9].

Increased awareness in health issues leads to increase the consumption of fruit juices and other natural products as an alternate to the traditional caffeine containing beverages such as tea, coffee or other soft drinks. Accompanying the increase in quantity of consumption, there has been a parallel increase in the variety of fruit juices and beverages offered for sale in the market [5]. Soft beverage industry has made significant progress during the last two decades in terms of rise in production and consumption; however, there is a limited range of fruit juice based RTS beverages available in the Indian market. Many types of syrups and soft drinks containing artificial fruit flavors are well known throughout the world. The basic factor considered is the nutritive and therapeutic values, which make them popular and acceptable $[10,11]$. At present fruit beverages are generally synthetic flavored, bottled and sold in the market. If this could be substituted with fruit juice and dairy whey, it will be more beneficial to the consumer, dairy industries and beverage manufacturers as well as fruit growers [12].
Therefore, it was found very interesting to utilize the milk whey as a water replacer for the development of a new delicious and nutritious RTS beverage from the ripe banana juice. The use of milk whey produces off-flavor in the beverages. The Mentha arvensis extract is commonly used as a natural flavoring agent in most of whey based fruit beverages to compensate the off-flavor of whey. It also acts as a good appetizer; acceptable to consumers and at the same time makes the product more palatable [13]. Looking to the fast growing market segment of functional beverages, it was felt appropriate to use the $M$. arvensis extract as natural flavoring agents in the development of whey based RTS beverage from ripe banana juice to fetch the higher market demand.

\section{Materials and Methods}

'Grand Naine' is a popular cultivar of banana grown mostly in all export oriented countries of Asia, South America and Africa [1]. The banana fruit having best quality, well matured and ready for ripening of 'Grand Naine' cultivar were procured from a local fruit market of Junagadh (Gujarat, India). The fruits were allowed to ripe under the natural conditions at room temperature. The banana fruits at ripening stage VII, as described by Robinson [14], were used for the juice preparation.

\section{Preparation of banana juice}

Natural banana juice was prepared without imparting any chemical/ enzymatic treatments as per the method suggested by Dhamsaniya [15]. The process flow diagram for the preparation of natural banana juice is shown in figure 1. The ripe banana fruits were washed with the chlorinated water followed by manual peeling and cutting into the

*Corresponding author: Dr. N. K. Dhamsaniya, Technical Officer, Junagadh Agricultural University, Junagadh-362001, Gujarat, India, Tel. +91-285-2671784; Fax +91-285-2672004; E-mail: nkdhamsania@yahoo.com

Received November 08, 2012; Accepted November 28, 2012; Published December 08, 2012

Citation: Dhamsaniya NK, Varshney AK (2013) Development and Evaluation of Whey Based RTS Beverage from Ripe Banana Juice. J Food Process Technol 4 203. doi:10.4172/2157-7110.1000203

Copyright: (c) 2013 Dhamsaniya NK, et al. This is an open-access article distributed under the terms of the Creative Commons Attribution License, which permits unrestricted use, distribution, and reproduction in any medium, provided the original author and source are credited. 


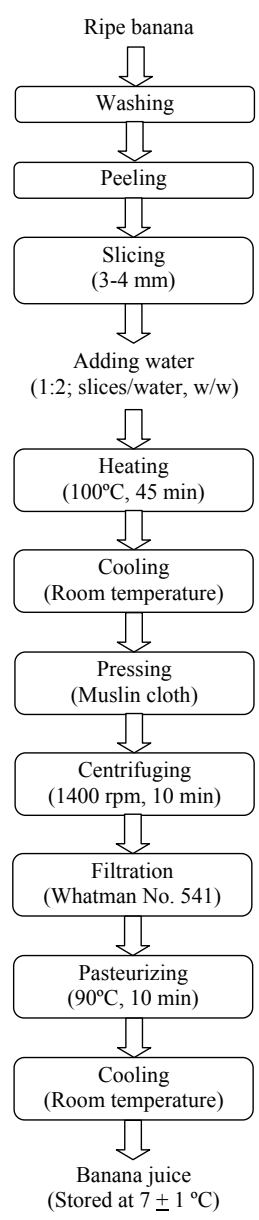

Figure 1: Process flow diagram for the preparation of natural banana juice.

slices of 3-4 $\mathrm{mm}$. The banana slices along with RO purified water in the ratio of 1:2 (banana slice : water, w/w) were heated at $100^{\circ} \mathrm{C}$ for 45 minutes followed by the cooling, pressing, centrifuging (at $1400 \mathrm{rpm}$ for $10 \mathrm{~min}$ ), filtration, pasteurization (at $90^{\circ} \mathrm{C}$ for $10 \mathrm{~min}$ ) and again cooling at room temperature. The prepared banana juice was stored at $7 \pm 1^{\circ} \mathrm{C}$ temperature in the refrigerator for further use in the RTS beverage preparation.

\section{Preparation of milk whey}

The milk whey was prepared following the procedure suggested by De [16] with slight modification (Figure 2). The "Taaza" brand standardized milk (3.1\% fat, 7.9\% SNF) was obtained from the Mother Dairy stall (Junagadh, Gujarat). The milk was boiled in a stainless steel vessel at $80^{\circ} \mathrm{C}$ for 10 minutes. The boiled milk after cooling to $72^{\circ} \mathrm{C}$ was acidified by adding 0.2 percent ( $2 \mathrm{~g}$ per $\mathrm{kg}$ of milk) citric acid (Eagle brand) followed by continuous stirring until the coagulation of milk proteins (casein) taken place. The mixture of milk whey and casein was allowed to cool at room temperature and then the whey was filtered using the muslin cloth. The milk whey thus obtained was filled in a glass bottle and stored in the refrigerator $\left(7 \pm 1^{\circ} \mathrm{C}\right)$ for further use.

\section{Preparation of $M$. arvensis extract}

The Mentha arvensis plant material was obtained from the main vegetable market of Junagadh (Gujarat, India). The fresh $M$. arvensis leaves were thoroughly washed in RO purified water and sanitized by using $20 \mathrm{ppm}$ chlorinated water as suggested by Tsen and King [17] The leaves were cut into small pieces and ground in the domestic mixergrinder followed by filtering through muslin cloth. The extract thus obtained was also stored in the refrigerator for further use.

\section{Preparation of RTS beverage}

The method described by Sirohi et al. [13] was followed in the preparation of whey banana RTS beverages. The proportion of banana juice, $M$. arvensis extract and milk whey was varied as presented in table 1 . The ground sugar powder was added at the rate of 8 gram per $100 \mathrm{ml}$. In each lot about 3.6 liters of beverage was prepared and the experiment was replicated thrice. The prepared beverages were filtered and filled into glass bottles $(200 \mathrm{ml})$ and sealed by crown corking. Then, the bottles were sterilized at $121^{\circ} \mathrm{C}$ for $10 \mathrm{~min}$ followed by cooling at room temperature.

\section{Physicochemical analysis}

The ELICO make digital $\mathrm{pH}$ meter (Model: LI 127) with an

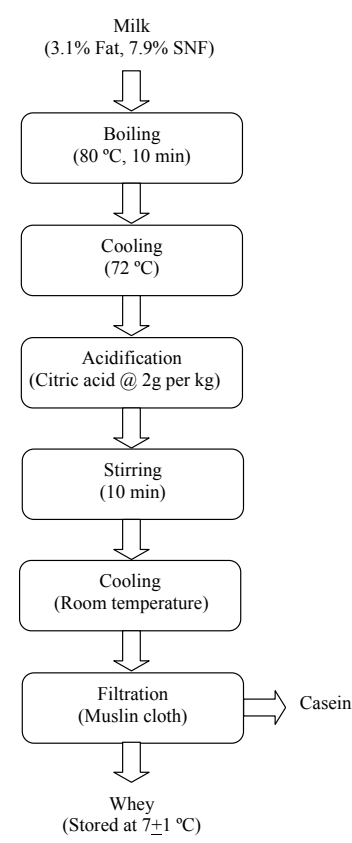

Figure 2: Process flow diagram for the milk whey preparation.

\begin{tabular}{|c|c|c|c|c|}
\hline Treatment & $\begin{array}{c}\text { Banana juice } \\
(\mathbf{m l})\end{array}$ & $\begin{array}{c}\text { M. arvensis } \\
\text { extract }(\mathbf{m l})\end{array}$ & $\begin{array}{c}\text { Milk whey } \\
(\mathbf{m l})\end{array}$ & $\begin{array}{c}\text { Sugar powder } \\
\mathbf{( g )}\end{array}$ \\
\hline $\mathrm{B}_{1}$ & 5 & 1 & 86 & 8 \\
\hline $\mathrm{B}_{2}$ & 5 & 3 & 84 & 8 \\
\hline $\mathrm{B}_{3}$ & 5 & 5 & 82 & 8 \\
\hline $\mathrm{B}_{4}$ & 10 & 1 & 81 & 8 \\
\hline $\mathrm{B}_{5}$ & 10 & 3 & 79 & 8 \\
\hline $\mathrm{B}_{6}$ & 10 & 5 & 77 & 8 \\
\hline $\mathrm{B}_{7}$ & 15 & 1 & 76 & 8 \\
\hline $\mathrm{B}_{8}$ & 15 & 3 & 74 & 8 \\
\hline $\mathrm{B}_{9}$ & 15 & 5 & 72 & 8 \\
\hline
\end{tabular}

"since the sugar powder was weighed in grams, the total volume of beverage was adjusted by the volume of whey (if required).

Table 1: Selected proportions of banana juice, M. arvensis extract and milk whey in the preparation of $100 \mathrm{ml}$ beverage. 
accuracy of 0.01 was used for $\mathrm{pH}$ measurement of the prepared beverages. The Total Soluble Solids (TSS) was determined by using the hand refractometer (Erma Inc., Tokyo: 0-32\%) following the method suggested by Dadzie and Orchard [18]. The observations were corrected using the temperature correction factor given by Askar and Treptow [19] and recorded in Brix. The reducing sugar and total sugar content in the beverage samples were determined by the methods suggested by Ranganna [20]. The titratable acidity in terms of percent citric acid equivalent was determined by the titration method against the standard $0.1 \mathrm{~N} \mathrm{NaOH}$ solution using phenolphthalein as an indicator as described by Ranganna [20]. The ascorbic acid content was determined by using 2-6 Dichlorophenol-indophenol (dye) visual titration method suggested by Askar and Treptow [21].

The browning index of beverage samples was determined as per the method given by Ranganna [20]. A sample of $0.5 \mathrm{~g}$ was taken in a test tube. Then, $10 \mathrm{ml}$ of $40 \%$ methanol was added in the sample. The sample was shaken thoroughly and kept for $12 \mathrm{~h}$ at room temperature. The solution was then filtered. The absorbance of filtrate was read at 420 $\mathrm{nm}$ in the UV-Visible Spectrophotometer (Model: Genesys 10, Thermo Scientific) and expressed as optical density (OD). The respective OD value represents the browning index of the sample concerned as suggested by Ranganna [20].

\section{Sensory analysis}

The prepared RTS beverage samples with varying levels of banana juice, $M$. arvensis extract and milk whey were presented to a panel of twelve experts comprising of faculty members and postgraduate students. The panelists were associated with the research and development of new food products at the department of processing and food engineering of College of Agricultural Engineering and Technology, Junagadh Agricultural University, Junagadh (Gujarat, India). A nine-point Hedonic scale score card was provided to the panelists to adjudge the quality of the product with respect to appearance, odor, taste and overall acceptability [22].

\section{Statistical analysis}

The data obtained during the physicochemical evaluation of the prepared RTS beverage samples were analyzed by SAS statistical software (version 9.1.3, SP4) using 2-factors 3-levels CRD with three replications. The Duncan's New Multiple Range Test (DNMRT) was used to compare the difference among the samples during the sensory evaluation.

\section{Results and Discussion}

The mean analyzed data showing effect of varying proportions of banana juice and $M$. arvensis extract on physicochemical properties of prepared RTS beverages are presented in table 2 . The values obtained are almost in agreement with the data reported by earlier researchers for whey based fruit beverages.

\section{Effect on pH}

The $\mathrm{pH}$ of prepared beverage was decreased remarkably from 4.74 to 4.37 with the increase in banana juice concentration (J) from 5 to 15 $\mathrm{ml}$ per $100 \mathrm{ml}$ of the prepared RTS beverage (Table 2). This indicated that the increase in the juice concentration decreased the active acidity in the prepared beverages. The effect of the juice concentration was found significant at even 1 percent level of significance. Also, the effect of varying the proportions of $M$. arvensis extract $(\mathrm{M})$ and also their interaction $(\mathrm{J} \times \mathrm{M})$ was found non-significant. The similar trend of $\mathrm{pH}$ was reported by Naik et al. [23] in case of whey based watermelon beverage.

\section{Effect on Total Soluble Solids (TSS)}

The increase in proportion of banana juice and M. arvensis extract significantly increased the TSS in the prepared RTS beverage. However, their interaction was found non-significant. The similar results were obtained by Theerachatpat [24], Sirohi et al. [13] and Naik et al. [23] in case of preparing the whey based banana powder, mango-pudina beverage and watermelon beverage, respectively.

\section{Effect on reducing sugar}

From table 2, it can be observed that the reducing sugar content was increased remarkably from 2.415 to 4.087 percent as the banana juice concentration increased from 5 to $15 \mathrm{ml}$ in the prepared RTS beverage. This indicated the highly significant effect of banana juice concentration on the reducing sugar content of the whey banana RTS beverage ( $\mathrm{P}$ $<0.01)$. The reverse trend was noticed in case of $M$. arvensis extract. The reducing sugar content was decreased from 3.278 to 2.965 percent with the increase in proportion of $M$. arvensis extract from 1 to $5 \mathrm{ml}$ in the prepared beverage. This indicated that the increase in amount

\begin{tabular}{|c|c|c|c|c|c|c|c|}
\hline Proportion per $100 \mathrm{ml}$ & $\mathrm{pH}$ & TSS $^{\circ}$ Brix & Reducing sugar $\%$ & Total sugar $\%$ & Titratable acidity $\%$ & Ascorbic acid $(\mathrm{mg} / 100 \mathrm{~g})$ & Browning index OD \\
\hline \multicolumn{8}{|l|}{ Banana juice $(\mathrm{J})$} \\
\hline $\mathrm{J}_{1}(5 \mathrm{ml})$ & 4.740 & 8.421 & 2.415 & 8.838 & 0.157 & 0.363 & 0.063 \\
\hline $\mathrm{J}_{2}(10 \mathrm{ml})$ & 4.638 & 9.634 & 2.863 & 10.468 & 0.222 & 0.660 & 0.071 \\
\hline $\mathrm{J}_{3}(15 \mathrm{ml})$ & 4.367 & 10.836 & 4.087 & 14.953 & 0.403 & 0.912 & 0.082 \\
\hline SEm \pm & 0.064 & 0.091 & 0.041 & 0.148 & 0.004 & 0.007 & 0.001 \\
\hline CD at $5 \%$ & 0.189 & 0.270 & 0.120 & 0.441 & 0.011 & 0.021 & 0.002 \\
\hline \multicolumn{8}{|l|}{ M. arvensis extract (M) } \\
\hline $\mathrm{M}_{1}(1 \mathrm{ml})$ & 4.667 & 9.418 & 3.278 & 11.989 & 0.240 & 0.632 & 0.067 \\
\hline $\mathrm{M}_{2}(3 \mathrm{ml})$ & 4.598 & 9.673 & 3.122 & 11.422 & 0.266 & 0.639 & 0.072 \\
\hline $\mathrm{M}_{3}(5 \mathrm{ml})$ & 4.480 & 9.800 & 2.965 & 10.848 & 0.276 & 0.664 & 0.076 \\
\hline $\mathrm{SEm} \pm$ & 0.064 & 0.091 & 0.041 & 0.148 & 0.004 & 0.007 & 0.001 \\
\hline CD at $5 \%$ & NS & 0.270 & 0.120 & 0.441 & 0.011 & 0.021 & 0.002 \\
\hline \multicolumn{8}{|l|}{ Interaction $(\mathrm{J}$ * $\mathrm{M})$} \\
\hline SEm \pm & 0.110 & 0.158 & 0.070 & 0.257 & 0.007 & 0.012 & 0.001 \\
\hline CD at $5 \%$ & NS & NS & NS & NS & 0.019 & NS & NS \\
\hline CV, \% & 4.16 & 2.83 & 3.89 & 3.90 & 4.30 & 3.23 & 2.47 \\
\hline
\end{tabular}

Table 2: Mean analyzed data showing effect of varying banana juice and $M$. arvensis extract proportion on physicochemical properties of prepared beverage. 
of $M$. arvensis extract reduced the rate of hydrolysis polysaccharides into sugars in the prepared beverage. However, the interaction of both the parameters ( $\mathrm{J}$ M) was found non-significant indicated the compensating effect of increasing in the proportion of banana juice and M. arvensis extract simultaneously.

\section{Effect on total sugar}

The total sugar content was also increased significantly with the increase in concentration of banana juice. This may be due to increase in banana juice quantity proportionately reduced the proportion of milk whey in the prepared RTS beverage. The results were found highly significant even at 1 percent level of significance. Similarly, the total sugar content was decreased with the increase in proportion of $M$. arvensis extract while their interaction was non-significant. The present findings are in agreement with the results reported by Sirohi et al. [13] in case of whey based mango-pudina beverage preparation.

\section{Effect on titratable acidity}

The titratable acidity was increased exponentially with the increase in proportion of either the banana juice or $M$. arvensis extract in the prepared RTS beverage. The analysis of data reported the highly significant effect of both the ingredients and their interaction ( $\mathrm{x} \mathrm{M})$ at 1 percent level of probability (Table 2). The increase in titratable acidity may be due to the acidic nature of both ingredients. Naik et al. [23] reported the similar findings in case of whey based watermelon beverage preparation.

\section{Effect on ascorbic acid content and browning index}

The increase in proportion of either the banana juice or M. arvensis extract in the prepared RTS beverage proportionally increased the ascorbic acid content and thereby browning in the beverages. The effect of both the ingredients were found highly significant $(\mathrm{P}<0.01)$. However, their interaction of data indicated the non-significant results as presented in table 2. The increase in browning may be due to the increase in polyphenoloxidase enzyme activity at higher proportion of either the banana juice or $M$. arvensis extract. The similar results were reported by Ingale et al. [6] in case of whey based custard apple beverage.

\section{Effect on sensory characteristics}

The mean sensory score assigned to the beverage samples prepared at different treatment is given in table 3 . The maximum mean sensory

\begin{tabular}{|c|c|c|c|c|}
\hline \multirow{2}{*}{ Treatment } & \multicolumn{4}{|c|}{ Mean sensory score } \\
\cline { 2 - 5 } & Appearance & Odor & Taste & Overall acceptability $^{\star}$ \\
\hline $\mathrm{B}_{1}$ & $6.00^{\mathrm{bc}}$ & $3.58^{\mathrm{g}}$ & $3.08^{\mathrm{f}}$ & $3.50^{\mathrm{h}}$ \\
\hline $\mathrm{B}_{2}$ & $5.75^{\mathrm{de}}$ & $4.75^{\mathrm{e}}$ & $4.67^{\mathrm{e}}$ & $4.75^{\mathrm{f}}$ \\
\hline $\mathrm{B}_{3}$ & $5.58^{\mathrm{e}}$ & $5.67^{\mathrm{c}}$ & $6.00^{\mathrm{b}}$ & $5.92^{\mathrm{bc}}$ \\
\hline $\mathrm{B}_{4}$ & $6.08^{\mathrm{b}}$ & $4.08^{\mathrm{f}}$ & $4.67^{\mathrm{e}}$ & $4.42^{\mathrm{g}}$ \\
\hline $\mathrm{B}_{5}$ & $5.83^{\mathrm{cd}}$ & $6.00^{\mathrm{b}}$ & $5.75^{\mathrm{cd}}$ & $5.75^{\mathrm{cd}}$ \\
\hline $\mathrm{B}_{6}$ & $5.67^{\mathrm{de}}$ & $6.83^{\mathrm{a}}$ & $5.92^{\mathrm{bc}}$ & $6.00^{\mathrm{b}}$ \\
\hline $\mathrm{B}_{7}$ & $6.17^{\mathrm{b}}$ & $5.08^{\mathrm{d}}$ & $5.92^{\mathrm{bc}}$ & $5.42^{\mathrm{e}}$ \\
\hline $\mathrm{B}_{8}$ & $6.58^{\mathrm{a}}$ & $6.75^{\mathrm{a}}$ & $7.83^{\mathrm{a}}$ & $7.33^{\mathrm{a}}$ \\
\hline $\mathrm{B}_{9}$ & $5.50^{\mathrm{e}}$ & $6.08^{\mathrm{b}}$ & $5.67^{\mathrm{d}}$ & $5.67^{\mathrm{d}}$ \\
\hline $\mathrm{SEm} \pm$ & 0.061 & 0.073 & 0.073 & 0.062 \\
\hline $\mathrm{CV}, \%$ & 12.48 & 16.21 & 15.92 & 13.82 \\
\hline
\end{tabular}

"mean values of the samples having same superscript letter are not significantly different $(P<0.01)$

Table 3: Effect of different treatment on sensory characteristics of the prepared beverage.

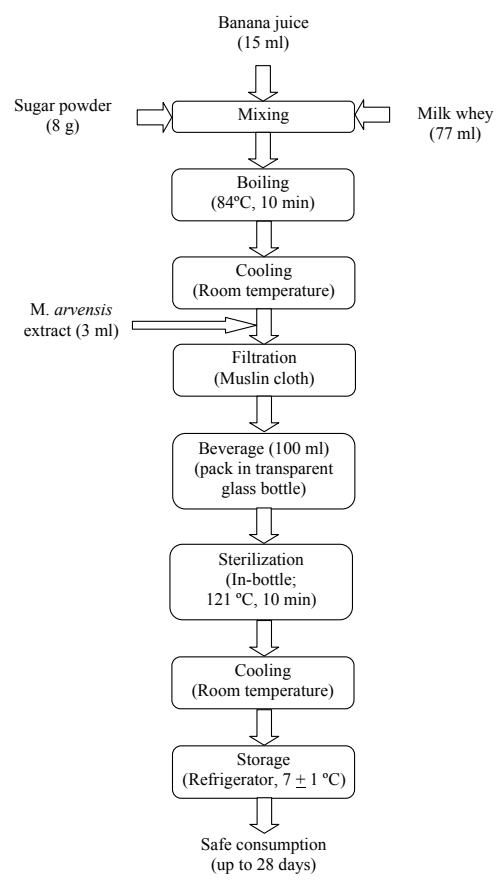

Figure 3: Suggested process flow diagram for the preparation of whey based RTS beverage from ripe banana juice.

score was obtained by the beverage sample of treatment $\mathrm{B}_{8}$ combination for the appearance, taste and overall acceptability attributes of sensory evaluation. Also, the mean sensory score of beverage sample $B_{6}$ combination was found maximum in case of odor attribute. But, the sample $B_{6}$ was found statistically at par with the sample $B_{8}$. Hence, the sample $\mathrm{B}_{8}$ having $15 \mathrm{ml}$ banana juice, $3 \mathrm{ml}$ M. arvensis extract, 8 g sugar powder and $77 \mathrm{ml}$ milk whey per $100 \mathrm{ml}$ of RTS beverage was found superior. The present findings are in conformity with the results reported by Naik et al. [23] for the sensory characteristics of whey based watermelon beverage.

As a result of various studies conducted for optimizing the proportion of ingredients; it was found that an acceptable whey based RTS beverage from ripe banana juice could be prepared using the suggested process flow diagram as depicted in figure 3. As shown, the mixture of $15 \mathrm{ml}$ banana juice, $8 \mathrm{~g}$ sugar powder and $77 \mathrm{ml}$ milk whey per $100 \mathrm{ml}$ of beverage should be boiled at $84^{\circ} \mathrm{C}$ temperature for 10 minutes followed by cooling at the room temperature. After cooling, 3 $\mathrm{ml} M$. arvensis extract should be added to the mixture for making the product more palatable and acceptable to the consumers. The prepared beverage should be filtered by muslin cloth and packed in airtight transparent glass bottle. After packing, the bottle should be sterilized at $121^{\circ} \mathrm{C}$ for 10 minutes followed by cooling at room temperature and then store in the refrigerator at $7 \pm 1^{\circ} \mathrm{C}$ temperature for the safe consumption.

\section{Conclusions}

It can be concluded that the RTS beverage could be prepared from the ripe banana juice and milk whey using $M$. arvensis extract as natural flavoring agent. The proportion of banana juice and $M$. arvensis extract may be taken as $15 \mathrm{ml}$ and $3 \mathrm{ml}$ per $100 \mathrm{ml}$ of the RTS beverage preparation for getting the optimum physicochemical characteristics and organoleptic quality, respectively. Also, looking to the higher nutritious virtues, the developed whey based RTS beverage from ripe 
Citation: Dhamsaniya NK, Varshney AK (2013) Development and Evaluation of Whey Based RTS Beverage from Ripe Banana Juice. J Food Process Technol 4: 203. doi:10.4172/2157-7110.1000203

Page 5 of 5

banana juice could be recommended for the large scale production at industrial level.

\section{Acknowledgements}

The authors are grateful to Junagadh Agricultural University for providing required facilities for conducting the research. Also, the authors express gratefulness to all the panelists for devoting their valuable time and taking keen interest in the sensory evaluation work.

\section{References}

1. Bhalerao VP, Patil NM, Badgujar CD, Patil DR (2009) Studies on integrated nutrient management for tissue cultured 'Grand Naine' banana. Indian J Agr Res 43: 107-112.

2. Yalcin S, Wade VN, Hassan Md N (1994) Utilization of chhana whey for the manufacture of soft drinks. J Food 19: 351-355.

3. Horton BS (1995) Whey processing and utilization. Information Bulletin International Dairy Federation, 308: 2-6.

4. Smithers GW (2008) Whey and whey proteins - From gutter-to-gold. Int Dairy J 18: 695-704.

5. Gagrani RL, Rathi SD, Ingle UM (1987) Preparation of fruit flavored beverage from whey. J Food Sci Technol 24: 93-94.

6. Ingale MP, Ranveer RC, Nagargoje KD (2009) Development of whey based custard apple (Annona Squamosa L.) beverage. Beverage \& Food World 36: 43-44.

7. Singh S, Ladkani BG, Kumar A, Mathur BN (1994) Development of whey based beverages. Indian J Dairy Sci 47: 586-590.

8. Singh W, Kapoor CM, Srivastava DN (1999) Standardization of technology for the manufacture of guava whey beverage. Indian J Dairy Sci 5: 268-271.

9. Shukla FC, Sharma A, Singh B (2004) Studies on the preparation of fruit beverages using whey and buttermilk. J Food Sci Technol 41: 102-104.

10. Balaswamy K, Rao PP, Nagender A, Satyanarayana A (2011) Preparation of sour grape (Vitis vinifera) beverages and evaluation of their storability. J Food Process Technol 2: 1000116.

11. Boghani AH, Raheem A, Hashmi SI (2012) Development and storage studies of blended papaya-aloe vera ready to serve (RTS) beverage. J Food Process Technol 3: 1000185.

12. Sakhale BK, Pawar VN, Ranveer RC (2012) Studies on the development and storage of whey based RTS beverage from Mango cv. Kesar. J Food Process Technol 3: 1000148.

13. Sirohi D, Patel S, Choudhary PL, Sahu C (2005) Studies on preparation and storage of whey-based mango herbal pudina (M. arvensis) beverage. J Food Sci Technol 42: 157-161.

14. Robinson JC, Sauco VG (2010) Bananas and plantains. ( $\left.2^{\text {nd }} e d n\right), C A B$ International, UK.

15. Dhamsaniya NK (2012) Development and storage of whey based banana beverage. Ph. D. thesis Junagadh Agricultural University, Junagadh, India.

16. De S (2001) Outlines of dairy technology. Oxford University Press, India

17. Tsen JH, King VAE (2002) Density of banana puree as a function of soluble solids concentration and temperature. J Food Eng 55: 305-308.

18. Dadzie BK, Orchard JE (1997) Routine post harvest screening of banana plantain hybrids: Criteria and methods. In: INIBAP Technical Guidelines 2. International Plant Genetic Resources Institute, France.

19. Askar A, Treptow H (1993) Total soluble solids. In: Quality assurance in tropica fruit processing. Springer Laboratory, New York, pp. 9-10.

20. Ranganna S (2004) Handbook of analysis and quality control for fruit and vegetable products. ( $2^{\text {nd }}$ edn), Tata McGraw-Hill Publication, India

21. Askar A, Treptow H (1993) Ascorbic acid. In: Quality assurance in tropical fruit processing. Springer Laboratory, New York, pp. 28-29.

22. Amerine MA, Pangborn RM, Roessler EB (1965) Principles of sensory evaluation of food. Academic Press, USA.

23. Naik YK, Khare A, Choudhary PL, Goel BK, Shrivastava A (2009) Studies on physicochemical and sensory characteristics of whey based watermelon beverage. Asian J Res Chem 2: 57-59.

24. Theerachatpat T (1999) Utilization of banana powder in ice cream and wheybased beverage. Unpublished report, Graduate School, Kasetsart University Thailand. 